\title{
PENERAPAN EVALUASI RANAH AFEKTIF SISWA DALAM PEMBELAJARAN BERBASIS KURIKULUM 2013 DI MADRASAH TSANAWIYAH NEGERI 2 KOTAMOBAGU
}

\author{
Jubair Ali \\ MTsN 1 Bolaang Mongondow Timur \\ Mangkoday Modayag Barat Bolaang Mongondow Timur \\ e-mail : jubairpaputungan@gmail.com
}

\begin{abstract}
Abstrak : Penelitian ini bertujuan untuk menganalisis penerapan, problematika, dan solusi evaluasi ranah afektif siswa pada pembelajaran berbasis kurikulum 2013 di MTs Negeri 2 Kotamobagu. Metodologi penelitian menggunakan pendekatan kualitatif. Teknik pengumpulan data menggunakan observasi, wawancara dan dokumen. Hasil penelitian yaitu: 1) Implementasi evaluasi ranah afektif di MTs Negeri 2 Kotamobagu secara umum sudah dilaksanakan namun belum maksimal 2) Problematika evaluasi ranah afektif di MTs Negeri 2 Kotamobagu, guru belum memahami dengan baik tentang pengukuran ranah afektif siswa, sehingga penilaian hanya berdasarkan pengamatan di dalam kelas, tanpa ada catatan tentang sikap siswa selama pembelajaran. 3) Solusi terhadap problematika evaluasi ranah afektif siswa di MTs Negeri 2 Kotamobagu berkaitan dengan teknik evaluasi, maka kepala madrasah menginstruksikan kepada guru untuk membuat laporan evaluasi sikap. Untuk mengatasi permasalahan berkaitan dengan pelanggaran terhadap ranah afektif siswa, maka guru melakukan bimbingan terhadap siswa di MTs Negeri 2 Kotamobagu.
\end{abstract}

\begin{abstract}
Research objectives to analyze the application, problems, and solutions to evaluation domain affective on learning based Kurikuum 2013 in MTs Negeri 2 Kotamobagu. Using techniques data collection observation, interviews and documents. The results are: 1) The implantation of the evaluation affective domain in MTS Negeri 2 Kotamobagu in generalization have been implementation, but unoptimized. 2) The problems of evaluation affective domain in MTs Negeri 2 Kotamobagu is teachers understand about measuring affective domain studen, that is implementation of assessment base direct observation in the classroom, without have note a students on the learning process. 3) The Solutions of problems to evaluation affective domain students in MTs Negeri 2 Kotamobagu relating to a technique evaluation, so the head madrasah instructed the teachers to make a report evaluation of attitude. To solve the problem pertaining to a violation of domain affective students, the teacher do guidance of students in MTs Negeri 2 Kotamobagu.
\end{abstract}

Kata Kunci : Evaluasi, Ranah Kognitif, Kurikulum 2013 


\section{Pendahuluan}

Program pendidikan dasar yang diatur Undang-Undang Nomor 20 tahun 2003 tentang Sistem Pendidikan Nasional, sebenarnya merupakan jawaban terhadap tuntutan zaman serta perkembangan ilmu pengetahuan, teknologi, dan seni yang menghendaki adanya berbagai peningkatan dan pembaruan (inovasi) di bidang pendidikan. Di samping itu dari sisi kebijakan pemerintah pendidikan dasar sembilan tahun merupakan kesinambungan dari keberhasilan pemerintah dalam menyelenggarakan program wajib belajar. ${ }^{1}$

Jadi, kebijakan-kebijakan pemerintah di bidang pendidikan tersebut intinya adalah perlunya peningkatan kualitas sumber daya manusia termasuk pengembangan kompetensi dari anak-anak pada semua jenjang pendidikan. Agar umat manusia mengetahui tentang kebesaran Allah Swt maka melalui belajarlah manusia dapat memahami dari kebesaran penciptaan dan kekuasaan Allah Swt. Dengan perantara pendidikan manusia akan dimuliakan oleh Allah Swt dalam kehidupannya. Nabi Adam as mulia karena dia belajar langsung kepada Allah Swt, sebagaimana firman-Nya Qs. Al-Baqarah/2:31 yaitu:

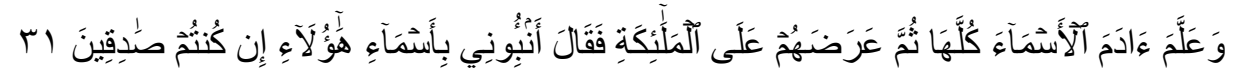

Terjemahnya:

Dan Dia mengajarkan kepada Adam nama-nama (benda-benda) seluruhnya, kemudian mengemukakannya kepada para Malaikat lalu berfirman: "Sebutkanlah kepada-Ku nama benda-benda itu jika kamu mamang benar orang-orang yang benar!". ${ }^{2}$

Di sini Allah Ta'ala membuktikan kelebihan Adam 'alaihis salam dalam hal ilmu, Allah mengajarkan kepadanya nama-nama benda semuanya lalu diperlihatkan-Nya kepada para malaikat sambil berfirman: "Beritahukanlah kepada-Ku nama-nama benda yang ada ini jika kamu memang benar", yakni memang benar lebih layak menjadi khalifah di muka bumi daripada Adam dan keturunannya. ${ }^{3}$

Selanjutnya hadis Nabi Muhammad Saw, yaitu:

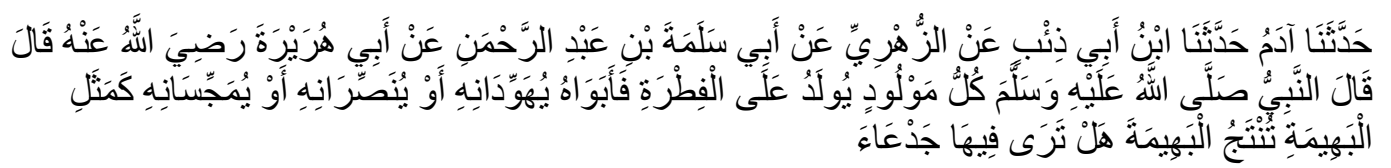

Artinya:

Telah menceritakan kepada kami [Adam] telah menceritakan kepada kami [Ibnu Abu Dza'bi] dari [Az Zuhriy] dari [Abu Salamah bin 'Abdurrahman] dari [Abu Hurairah radliallahu 'anhu] berkata; Nabi Shallallahu'alaihiwasallam bersabda: "Setiap anak dilahirkan dalam keadaan fithrah. Kemudian kedua orang tuanyalah yang akan menjadikan anak itu menjadi Yahudi, Nasrani atau Majusi

${ }^{1}$ Undang-Undang Nomor 20 tahun 2003 tentang Sistem Pendidikan Nasional, pasal 1

${ }^{2}$ Departemen Agama RI, Al-Qur'an Transliterasi Latin Terjemah Indonesia, Jakarta: Suara Agung, 2015, h.9

${ }^{3}$ Abu Yahya Marwan bin Musa, Tafsir Al Qur'an Hidayatul Insan, Jilid 1., h.20 
sebagaimana binatang ternak yang melahirkan binatang ternak dengan sempurna. Apakah kalian melihat ada cacat padanya?". (HR. Bukhari dan Muslim). ${ }^{4}$

Dari uraian di atas menunjukkan bawah setiap anak itu dilahirkan dalam keadaan fitrah (suci) dan mempunyai potensi yang cukup luas. Tergantung bagaimana kita mendidik anak tersebut agar dapat bermanfaat bagi orang banyak. Tersirat didalamnya bahwa pentingnya pengembangan ranah kongnitif (pengetahuan), afektif (sikap) dan psikomotor (keterampilan) anak sehingga menjadi lebih baik di kemudian hari. Ranah kompetensi sebagaimana uraian di atas memegang peranan penting dalam upaya peningkatan prestasi siswa di madrasah. Ranah kognitif menitikberatkan pada peningkatan kemampuan siswa berkaitan dengan materi yang diajarkan, ranah afektif berkaitan dengan memperbaiki sikap siswa, sedangkan psikomotor (keterampilan) diarahkan pada kemampuan siswa untuk mengimplementasikan apa yang dipelajari oleh anak tersebut. Hal ini perlu dilakukan evaluasi terhadap peningkatan kompetensi yang difokuskan pada ranah kognitif, afektif dan psikomotor.

Berdasarkan uraian di atas, maka penelitian berkaitan dengan evaluasi pengembangan ranah afektif siswa di MTs Negeri 2 Kotamobagu penting dilakukan. Hal ini sangatlah penting mengingat dengan adanya perubahan kurikulum yang menekankan pada 3 (tiga) ranah tersebut maka guru di MTs Negeri 2 Kotamobagu juga harus menyiapkan instrumen-instrumen dan melakukan evaluasi terhadap ranah kognitif, afektif, dan psikomotor siswa. Instrumen pengukuran kognitif diarahkan pada tes (tertulis non lisan), instrumen pengukuran afektif diarahkan pada observasi dan penilaian antar teman, dan instrumen psikomotor diarahkan pada pengamatan dalam bentuk unjuk kerja dan produk (hasil kerja). Namun pengukuran dari guru lebih dominan pada ranah kognitif dan psikomotor siswa, sedangkan ranah afektif seringkali hanya dijadikan pelengkap oleh guru di MTs Negeri 2 Kotamobagu. Untuk itu pengukuran ranah afektif siswa oleh guru perlu di teliti sehingga dapat diketahui sudah sejauhmana pengukuran ranah afektif siswa. Sebagaimana uraian di atas maka instrumen pengukuran ranah afektif yaitu observasi dan penilaian antar teman, hal ini sesuai dengan ketentuan sebagaimana dalam kurikulum 2013. Evaluasi pada ranah afektif siswa yang dilakukan oleh guru dengan adanya kurikulum 2013 terjadi perubahan yang signifikan di mana ranah afektif merupakan bagian dari kompetensi siswa. untuk itu perlu dilakukan evaluasi ranah afektif, sehingga guru dapat mengetahui ketercapaian kompetensi ranah afektif siswa pada MTs Negeri 2 Kotamobagu. Teknik pengumpulan data menggunakan observasi, wawancara dan dokumen. Dengan prosedur analisis data yaitu: pengumpulan data, reduksi data, tampilan data, dan pengambilan kesimpulan.

\section{Kajian Teoretik}

\section{Hakikat Belajar}

Belajar merupakan proses manusia untuk mencapai berbagai macam kompetensi, keterampilan, dan sikap. Usaha untuk mencapai kepandaian atau ilmu merupakan usaha manusia untuk memenuhi kebutuhannya, mendapatkan ilmu atau kepandaian yang belum dipunyai sebelumnya. Sehingga dengan belajar manusia menjadi tahu, memahami, mengerti, dapat melaksanakan dan memiliki tentang sesuatu. Dalam keseluruhan proses pendidikan di sekolah kegiatan belajar mengajar merupakan

\footnotetext{
${ }^{4}$ Hadits riwayat Bukhari dan Muslim dari Abu Hurairah no. 1296
} 
kegiatan paling pokok. Hal ini berarti bahwa keberhasilan atau tidaknya pencapaian tujuan pendidikan bergantung pada proses belajar yang dilakukan siswa sebagai anak didik. $^{5}$

\section{Evaluasi Pembelajaran}

Istilah evaluasi pembelajaran sering disamaartikan dengan ujian. Meskipun saling berkaitan, akan tetapi tidak mencakup keseluruhan makna yang sebenarnya. Ujian ulangan harian yang dilakukan guru di kelas atau bahkan ujian akhir sekolah sekalipun, belum dapat menggambarkan esensi evaluasi pembelajaran, terutama bila dikaitkan dengan penerapan kurikulum 2013. Sebab, evaluasi pembelajaran pada dasarnya bukan hanya menilai hasil belajar, tetapi juga proses-proses yang dilalui pendidik dan peserta didik dalam keseluruhan proses pembelajaran. ${ }^{6}$

Selanjutnya, istilah evaluasi telah diartikan para ahli dengan cara berbeda meskipun maknanya relatif sama. Guba dan Lincoln, misalnya, mengemukakan definisi evaluasi sebagai "a process for describing an evaluation and judging its merit and worth". 7 Sedangkan Gilbert Sax berpendapat bahwa "evaluation is a process through which a value judgement or decision is made from a variety of observations and from the background and training of the evaluator". 8

\section{Ranah Afektif (Sikap) dalam Perspektif Kurikulum 2013}

Penilaian sikap merupakan kegiatan untuk mengetahui kecenderungan perilaku spiritual dan sosial peserta didik dalam kehidupan sehari-hari, baik di dalam maupun di luar kelas sebagai hasil pendidikan. Penilaian sikap ditujukan untuk mengetahui capaian atau perkembangan sikap peserta didik dan memfasilitasi tumbuhnya perilaku peserta didik sesuai butir-butir nilai sikap dari KI-1 (Kompetensi Spiritual) dan KI-2 (Kompetensi Sosial). ${ }^{9}$

Afektif berhubungan dengan nilai (value), yang sulit diukur, oleh karena menyangkut kesadaran seseorang yang tumbuh dari dalam. Dalam batas tertentu memang afeksi dapat muncul dalam kejadian behavioral (tingkah laku), akan tetapi penilaiannya untuk sampai pada kesimpulan yang bisa dipertanggungjawabkan membutuhkan ketelitian dan observasi terus menerus, dan hal ini tidaklah mudah dilakukan, apalagi menilai perubahan sikap akibat dari proses pembelajaran yang dilakukan guru di madrasah. ${ }^{10}$

\footnotetext{
${ }^{5}$ Slameto, Belajar dan Faktor-faktor yang Mempengaruhinya (Jakarta: Rineka Cipta, 2013), h.13

${ }^{6}$ Asrul, Rusydi Ananda, Rosnita, Evaluasi Pembelajaran (Bandung: Citapustaka Media, 2014), h. 2

7 Ngalim Purwanto, Prinsip-Prinsip dan Teknik Evaluasi Pengajaran (Bandung: Remaja Rosdakarya, 2000), h.35

${ }^{8}$ Syafruddin Nurdin, Adriantoni, Kurikulum dan Pembelajaran, (Jakarta: Rajawali Pers, 2016), h.48

9 Kementerian Pendidikan dan Kebudayaan, Panduan Penilaian Oleh Pendidik dan Satuan Pendidikan Untuk Sekolah Menengah Pertama (Jakarta: Direktorat Pendidikan Dasar dan Menengah, 2016), h.21

${ }^{10}$ Wina Sanjaya, Strategi Pembelajaran Berorientasi Standar Proses Pendidikan (Jakarta: Prenada Media Group, 2006), h.274
} 
Dari uraian di atas menunjukkan bahwa sikap merupakan bagian terpenting dalam mengembangkan kompetensi siswa. Hal ini sejalan dengan kurikulum yang berlaku sekarang ini yaitu kurikulum 2013. Untuk itu perlu dibuat instrumen pengukuran dan evaluasi terhadap hasil penilaian sikap sehingga guru dapat mengetahui perkembangan ranah afektif siswa selama proses pembelajaran.

Untuk melakukan penilaian afektif (Sikap) dalam kurikulum 2013 yaitu:

a. Observasi; Penerapan teknik observasi dapat dilakukan menggunakan lembar observasi. Lembar observasi merupakan instrumen yang dapat digunakan oleh pendidik untuk memudahkan dalam membuat laporan hasil pengamatan terhadap perilaku peserta didik yang berkaitan dengan sikap spiritual dan sikap sosial. Sikap yang diamati adalah sikap yang tercantum dalam indikator pencapaian kompetensi pada KD untuk mata pelajaran PABP (Pendidikan Agama dan Budi Pekerti) dan PPKn. Pada mata pelajaran selain PABP dan PPKn, sikap yang diamati tercantum pada Kompetensi Inti-1 (sikap spiritual) dan Kompetensi Inti-2 (sikap sosial). ${ }^{11}$

b. Penilaian Diri; Penilaian diri dalam penilaian sikap merupakan teknik penilaian terhadap diri sendiri (peserta didik) dengan mengidentifikasi kelebihan dan kekurangan sikapnya dalam berperilaku. Hasil penilaian diri peserta didik dapat digunakan sebagai data konfirmasi perkembangan sikap peserta didik. Selain itu penilaian diri peserta didik juga dapat digunakan untuk menumbuhkan nilai-nilai kejujuran dan meningkatkan kemampuan refleksi atau mawas diri. ${ }^{12}$

c. Penilaian Antar Teman; Penilaian antar teman merupakan teknik penilaian yang dilakukan oleh seorang peserta didik (penilai) terhadap peserta didik. Sebagaimana penilaian diri, hasil penilaian antar teman dapat digunakan sebagai data konfirmasi. penilaian antar teman juga digunakan untuk menumbuhkan nilai seperti kejujuran, tenggang rasa, dan saling menghargai. ${ }^{13}$

Instrumen penilaian diri dapat berupa lembar penilaian diri yang berisi butir-butir pernyataan sikap positif yang diharapkan dengan kolom YA dan TIDAK atau dengan Likert Scale. Satu lembar penilaian diri dapat digunakan untuk penilaian sikap spiritual dan sikap sosial sekaligus. Hal ini menjadi sangat penting agar supaya dalam menyusun instrumen dapat memperhatikan skala pengukurannya. Dengan skala pengukuran yang cocok atau sesuai maka mempermudah mendapatkan data yang dibutuhkan dalam penilaian sikap. ${ }^{14}$

Dalam kurikulum 2013 indikator-indikator dalam ranah afektif terbagi dalam 2 (dua) bagian yaitu sikap spiritual dan sosial. Indikator-indikatornya sebagaimana uraian di bawah ini:

a. Sikap spiritual yang dapat digunakan dan dinilai pada semua mata pelajaran: 1) Berdoa sebelum dan sesudah melakukan kegiatan; 2) Menjalankan ibadah sesuai dengan agamanya; 3) Memberi salam pada saat awal dan akhir kegiatan; 4) Bersyukur atas nikmat dan karunia Tuhan Yang Maha Esa; 5) Mensyukuri kemampuan manusia dalam mengendalikan diri; 6) Bersyukur ketika berhasil mengerjakan tugas atau ujian; 7) Berserah diri (tawakal) kepada Tuhan setelah berikhtiar atau berusaha; 8) Memelihara hubungan baik sesama umat ciptaan

\footnotetext{
${ }^{11}$ Kementerian Pendidikan dan Kebudayaan, Panduan ....,h. 21

${ }^{12}$ Kementerian Pendidikan dan Kebudayaan, Panduan ..., h. 28

${ }^{13}$ Kementerian Pendidikan dan Kebudayaan, Panduan ...,h.30

${ }^{14}$ Kementerian Pendidikan dan Kebudayaan, Panduan ..., h.31
} 
Tuhan Yang Maha Esa; 9) Bersyukur kepada Tuhan Yang Maha Esa sebagai bangsa Indonesia; 10) Menghormati orang lain yang menjalankan ibadah sesuai agamanya.

b. Sikap sosial untuk semua mata pelajaran: 1) Jujur, yaitu perilaku dapat dipercaya dalam perkataan, tindakan, dan pekerjaan; 2) Disiplin, yaitu tindakan yang menunjukkan perilaku tertib dan patuh pada berbagai ketentuan dan peraturan; 3) Tanggung jawab, yaitu sikap dan perilaku seseorang untuk melaksanakan tugas dan kewajibannya, yang seharusnya dia lakukan, terhadap diri sendiri, masyarakat, lingkungan (alam, sosial dan budaya), negara dan Tuhan Yang Maha Esa; 4) Santun, yaitu sikap baik dalam pergaulan baik dalam berbahasa maupun bertingkah laku. Norma kesantunan bersifat relatif, artinya yang dianggap baik/santun pada tempat dan waktu tertentu bisa berbeda pada tempat dan waktu yang lain; 5) Percaya diri, yaitu suatu keyakinan atas kemampuannya sendiri untuk melakukan kegiatan atau tindakan; 6) Peduli, adalah sikap dan tindakan yang selalu berupaya mencegah dan memperbaiki penyimpangan dan kerusakan (manusia, alam, dan tatanan. ${ }^{15}$

\section{Hasil Penelitian dan Pembahasan}

\section{Penerapan Evaluasi Ranah Afektif Siswa pada Pembelajaran Berbasis Kurikulu 2013 di MTs Negeri 2 Kotamobagu}

Di MTs Negeri 2 Kotamobagu sudah menggunakan kurikulum 2013 artinya seluruh sistem pembelajarannya harus berbasis kurikulum 2013 mulai dari perencanaan pembelajaran, pengorganisasian pembelajaran pelaksanaan pembelajaran, serta pengawasan pembelajaran. Sebagaimana tujuan ini yaitu evaluasi ranah afektif, di mana ranah afektif merupakan bagian dari fungsi-fungsi manajemen yaitu pada fungsi pengawasan. Di mana fungsi pengawasan tersebut termasuk adalah kegiatan evaluasi.

Selanjutnya hasil wawancara berkaitan dengan implementasi ranah afektif siswa pada kelas proses pembelajaran kurikulum 2013 di MTs Negeri 2 Kotamobagu, yaitu:

Hasil wawancara berkaitan dengan pemahaman guru tentang evaluasi ranah afektif di MTs Negeri 2 Kotamobagu. "Pada awal diberlakukan kurikulum 2013 ini, memang saya sebagai kepala sekolah merasah bingung karena, banyak kendala yang dihadapi. Di lingkungan guru itu sendiri memang ada yang sudah memahami kurikulum dan ada yang belum. Jadi sebagai pimpinan di madrasah saya menugaskan beberapa orang untuk mengsosialisasikan tentang kurikulum 2013 ini. Hal ini sesuai dengan kebijakan pemerintah untuk tetap mengimplementasikan kurikulum 2013. Memang untuk ranah afektif menjadi bagian dari kurikulum, artinya anak itu tidak hanya dibekali dengan kompetensi secara kognitif akan tetapi dibekali juga secara afektif dan psikomotor. Ranah afektif menurut saya memegang peranan penting, karena berkaitan dengan membangun sikap anak baik itu di madrasah maupun di luar madrasah. Selah selalu melakukan monitoring dan menanyakan perkembangan penilaian dan salah satunya adalah ranah afektif". 16 "Dalam pengorganisasian implementasi ranah afektif di MTs Negeri 2 Kotamobagu merupakan tugas dari wakil kepala madrasah bidang kurikulum. Disamping itu juga guru kelas sebagai penanggung jawab siswa di dalam

\footnotetext{
${ }^{15}$ Kementerian Pendidikan dan Kebudayaan, Panduan ..., h.30

${ }^{16}$ Hasil wawancara dengan AM Kepala MTs Negeri 2 Kotamobagu pada tanggal 3 Juli 2018
} 
kelas harus mampu membuat merangkum penilaian-penilaian yang dibuat oleh guru bidang studi". 17

Uraian di atas menunjukkan awal berlakunya kurikulum 2013 Kepala madrasah masih belum memahaminya, karena pada saat munculnya kurikulum 2013 ini, terjadi perubahan yang signifikan jika dibandingkan dengan kurikulum tingkat satuan pendidikan (KTSP), sehingga harus memahami konteks evaluasi ranah afektif berbasis kurikulum 2013. Dengan adanya berbagai pelatihan dan belajar autodidak. Kegiatankegiatan pada implementasi ranah afektif di madrasah, berdasarkan pada penyusunan program tahunan dan program semester. Kepala madrasah memahami konsep dari kurikulum 2013, dimana pengembangan kompetensi siswa dapat mencakup 3 (tiga) aspek yaitu ranah afektif, kognitif dan psikomotor. Ranah afektif memegang peranan penting dalam meningkatkan kompetensi sehingga Kepala madrasah selalu melakukan pengawasan tentang perkembangan siswa di MTs Negeri 2 Kotamobagu.

Masih banyak guru yang kurang memahami tentang implementasi dari pengembangan ranah afektif guru dalam pembelajaran, namun kepala madrasah selalu memantau atau mengawasi dari kegiatan-kegiatan yang dilakukan oleh guru di MTs Negeri 2 Kotamobagu. Untuk itu diperlukan bimbingan teknis baik itu dalam bentuk individual maupun kelompok guru di MTs Negeri 2 Kotamobagu.

\section{Problematika Penerapan Evaluasi Ranah Afektif Pada Pembelajaran Berbasis Kurikulum 2013 di MTs Negeri 2 Kotamobagu}

Wawancara berkaitan dengan problematika penerapan evaluasi ranah afektif siswa pada pembelajaran berbasis kurikulum 2013 di MTs Negeri 2 Kotamobagu, sebagaimana uraian di bawah ini:

Permasalahan evaluasi ranah afektif terhadap siswa. Hasil wawancara dengan kepala MTs Negeri 2 Kotamobagu, yaitu: "Berdasarkan hasil monitoring saya terhadap guru-guru dalam melakukan evaluasi pada ranah afektif, saya merasa belum lengkap karena biasanya untuk aspek sikap, hanya melihat anak-anak yang dianggap nakal di kelas, itupun hanya ditangani oleh wali kelas. menurut saya semua yang ada di madrasah harus bertanggung jawab, agar supaya ada perubahan dari anak terebut. Penanganan terhadap siswa yang sikapnya masih rendah belum maksimal. Perlu adanya penanganan lebih lanjut oleh guru, dengan melakukan pengawasan dan evaluasi terhadap perubahan sikap siswa di MTs Negeri 2 Kotamobagu"18

Hal ini dapat dimaknai bahwa guru-guru menerapkan penilaian ranah afektif hanya bersifat kasuistik yaitu melihat siswa-siswa yang nakal dan ditangani oleh guru itu sendiri. Belum melakukan penilaian secara komprehensif tentang ranah afektif siswa.

Permasalahan pemahaman guru terhadap evaluasi ranah afektif siswa. Hasil wawancara dengan wakil kepala madrasah bagian kurikulum, yaitu: "Menurut saya kurikulum 2013 ini sangat baik apabila diterapkan dengan baik, guru harus memahami kurikulum tersebut, sehingga dapat mengimplementasikannya. Akan tetapi masih

\footnotetext{
${ }^{17}$ Hasil wawancara dengan AM Kepala MTs Negeri 2 Kotamobagu pada tanggal 3 Juli 2018

${ }^{18}$ Hasil wawancara dengan Inisial AM Kepala MTs Negeri 2 Kotamobagu pada tanggal 9 Juli 
banyak guru yang tidak memahami secara jelas, dan bahkan ada yang berbeda pendapat, sehingga secara umum guru masih merasa bingung. Kemampuan menyusun instrumen penilaian ranah afektif, belum berjalan dengan baik, sehingga instrumen yang dibuat hanya berdasarkan kurikulum dahulu, pada hal sudah ada perubahan. Perlu ada kajian lebih lanjut tentang evaluasi ranah afektif, termasuk penyusunan instrumen dan penggunaan instrumen selama pembelajaran"19

Dari uraian di atas menunjukkan secara umum kurikulum 2013 sangat baik, akan tetapi guru kurang memahami tentang penilaian pada ranah afektif, yang sangat terlihat pada penyusunan instrumen penilaian ranah afektif.

Membandingkan penilaian ranah afektif siswa menggunakan KTSP dan K-13. Hasil wawancara dengan guru MTs Negeri 2 Kotamobagu, yaitu: "Menurut saya sebelumnya adanya kurikulum 2013 guru selalu mengembangkan ranah afektif siswa, di mana guru selalu memberikan peringatan terhadap anak yang nakal serta selalu mengawasi anak-anak yang bermasalah, akan tetapi penanganannya hanya sebatas memberikan nasihat dan hukuman saja. Pada hal dalam kurikulum 2013 ranah afektif siswa harus dinilai selama proses pembelajaran, hal ini yang menjadi halangan, di satu sisi ingin mengembangkan pengetahuan di sisi lain guru harus melakukan penilaian terhadap ranah afektif siswa". ${ }^{20}$

Hal ini dapat dimaknai bahwa guru telah melakukan penilaian ranah afektif terhadap siswa. Guru selalu melakukan pengawasan terhadap anak-anak yang bermasalah dengan memberi nasihat dan hukuman. Namun untuk melakukan pengawasan selama proses pembelajaran pada semua siswa di Kelas menjadi halangan guru dalam proses pembelajaran. Halangan tersebut berupa guru hanya terfokus pada pencapaian tujuan pembelajaran berkaitan dengan pengembangan pengetahuan siswa, sehingga terkadang melupakan penilaian ranah afektif siswa di MTs Negeri 2 Kotamobagu.

\section{Solusi Problematika Penerapan Evaluasi Ranah Afektif Siswa dalam Pembelajaran Berbasis Kurikurum 2013 di MTs Negeri 2 Kotamobagu}

Wawancara berkaitan dengan menganalisis Solusi Problematika Penerapan Evaluasi Ranah Afektif Siswa dalam Pembelajaran Berbasis Kurikurum 2013 di MTs Negeri 2 Kotamobagu: Wawancara dengan kepala MTs Negeri 2 Kotamobagu, yaitu: "Dalam pembelajaran terlihat hanya guru kelas yang melakukan pengamatan terhadap sikap atau ranah afektif siswa, pada hal harus semua guru bertanggung jawab terhadap ranah afektif siswa, sehingga saya sebagai pimpinan melakukan sosialisasi secara individual kepada guru, agar membuat laporan tentang sikap siswa selama pembelajaran"

"Ada keterkaitan antara pengembangan ranah afektif dengan hasil belajar siswa. Pengembangan ranah afektif dalam hal ini sikap baik maka pengetahuan juga baik, namun tidak menutup kemungkinan juga berbeda. untuk itu guru harus mampu

\footnotetext{
${ }^{19}$ Hasil wawancara dengan wakil kepala madrasah Inisial DSP di MTs Negeri 2 Kotamobagu pada tanggal 5 Juli 2018

${ }^{20}$ Hasil wawancara dengan guru Inisial LU di MTs Negeri Kotamobagu, pada tanggal 9 Juli 2018
} 
mengembangkan ranah afektif ini sehingga berpengaruh terhadap hasil belajar siswa". ${ }^{21}$ Ada beberapa anak di Kelas VII yang mempunyai motivasi rendah dalam belajar, terlihat hanya banyak bermain di dalam kelas, setelah saya cek nilai ujian hariannya banyak yang tidak tuntas, di kelas VII rata-rata yang rajin belajar dan disiplin waktu dalam belajar mempunyai nilai ketuntasan kriterian minimum atau KKM sehingga jalan keluarnya adalah saya harus menekan kepada guru untuk pengembangan ranah afektif siswa agar lebih optimal". ${ }^{22}$

Di maknai guru kelas yang dominan untuk melakukan penilaian terhadap ranah afektif (sikap) siswa, sementara tuntutan Kurikulum 2013 mengharuskan untuk semua guru bertanggung jawab terhadap ranah afektif siswa. Hal yang dilakukan oleh Kepala MTs Negeri 2 Kotamobagu yaitu melakukan bimbingan terhadap guru dan memberikan penugasan agar guru-guru membuat laporan perkembangan ranah afektif siswa.

\section{Pembahasan}

\section{Penerapan Evaluasi Ranah Afektif siswa pada Pembelajaran Berbasis Kurikulum 2013 di MTs Negeri 2 Kotamobagu}

Adanya kebijakan dari pemerintah tentang penerapan kurikulum 2013 maka MTs Negeri 2 Kotamobagu juga harus menggunakan kurikulum tersebut, salah satunya adalah Evaluasi ranah afektif yang dilakukan oleh guru terhadap siswa. Evaluasi ranah afektif yaitu melakukan analisis secara detail dalam bentuk laporan terhadap ranah yang berkaitan dengan sikap dan nilai. Ranah afektif mencakup sikap, minat, konsep diri dan nilai. $^{23}$

Menurut Sukanti, dalam proses pembelajaran terdapat empat tipe karakteristik afektif yang penting yaitu:

a. Sikap adalah suatu predisposisi yang dipelajari untuk merespon secara positif atau negatif terhadap suatu objek, situasi, konsep atau orang. Misalnya objeknya adalah sikap peserta didik terhadap mata pelajaran pendidikan agama Islam. Seharusnya sikap peserta didik terhadap mata pelajaran di MTs Negeri 2 Kotamobagu lebih positif dibanding sebelum mengikuti proses pembelajaran. Perubahan sikap ini merupakan indikator keberhasilan pendidik dalam proses pembelajaran. Oleh karena itu pendidik harus membuat rencana pembelajaran termasuk pengalaman pembelajaran yang membuat sikap peserta didik terhadap mata pelajaran menjadi lebih positif. Dengan sikap positif dalam diri peserta didik akan lebih mudah diberi motivasi dan akan lebih mudah menyerap materi pelajaran yang diajarkan. Penilaian sikap di MTs Negeri 2 Kotamobagu ada dua yaitu sikap mengikuti pembelajaran sehari-hari dan sikap dalam melaksanakan suatu pekerjaan produktif. Sikap mengikuti pembelajaran bersumber dari catatan harian peserta didik berdasarkan pengamatan guru mata pelajaran, hasil penilaian berdasarkan pertanyaan langsung dan laporan pribadi. Penilaian sikap dalam melaksanakan pekerjaan idealnya dilakukan oleh dua penilai yaitu unsur eksternal (dari orang tua)

\footnotetext{
${ }^{21}$ Hasil wawancara dengan inisial AM Kepala MTs Negeri Kotamobagu, pada tanggal 10 Juli 2018

22 Hasil wawancara dengan wakil kepala madrasah Inisial DSP di MTs Negeri 2 Kotamobagu pada tanggal 5 Juli 2018

${ }^{23}$ Ahmad Darmadji, "Urgensi Ranah Afektif Dalam Evaluasi Pendidikan Agama Islam di Perguruan Tinggi Umum”, Jurnal Unisia, Vol. XXXIII (74) Tahun 2014
} 
dan internal (guru), yang mengacu pada pencapaian kriteria pada setiap kompetensi. Sikap yang dinilai adalah sikap yang dipersyaratkan dalam pembelajaran. ${ }^{24}$

b. Minat adalah suatu rasa lebih suka dan rasa ketertarikan pada suatu aktivitas tanpa ada yang menyuruh. Minat berhubungan dengan perhatian, seseorang yang menaruh minat pada mata pelajaran tertentu cenderung untuk memperhatikan mata pelajaran tersebut. Dengan demikian peserta didik yang berminat pada materi belajar cenderung memperhatikan mata pelajaran tersebut, di MTs Negeri 2 Kotamobagu para siswa yang aktif dalam pembelajaran merupakan indikasi bahwa siswa tersebut mempunyai minat terhadap pembelajaran. Untuk itu guru di MTs Negeri 2 Kotamobagu harus memahami minat dari siswa tersebut, indikasinya yaitu adanya perasaan suka, ketertarikan, perhatian, kesesuaian, kecenderungan untuk menindaklanjuti (tugas yang diberikan guru). ${ }^{25}$

c. Nilai merupakan suatu keyakinan tentang perbuatan, tindakan, atau perilaku yang dianggap baik dan yang dianggap jelek. Beberapa ranah afektif yang tergolong penting, yaitu: 1) Kejujuran: peserta didik harus belajar untuk menghargai kejujuran dalam berinteraksi dengan orang lain; 2) Integritas: peserta didik harus dapat dipercaya oleh orang lain, mengikat pada kode nilai; 3) Adil: peserta didik harus berpendapat bahwa semua orang memperoleh perlakuan hukum yang sama; 4) Kebebasan: peserta didik harus yakin bahwa negara demokratis harus memberi kebebasan secara maksimum kepada semua orang. ${ }^{26}$

Perlu penanaman nilai-nilai yang baik pada siswa di MTs Negeri 2 Kotamobagu dengan memperhatikan kejujuran, integritas, adil, kebebasan yang positif. Penanaman kejujuran yang paling sederhana yaitu mengerjakan ujian dengan kepercayaan diri yang tinggi (tidak menyontek), integritas yang dimiliki oleh para siswa dalam belajar, sehingga ada keinginan untuk terus menerus meningkatkan kemampuannya di madrasah.

d. Konsep diri adalah evaluasi yang dilakukan individu terhadap kemampuan dan kelemahan yang dimilikinya. Konsep diri ini penting bagi peserta didik untuk menentukan jenjang karier mereka yaitu dengan mengetahui kekuatan dan kelemahan diri sendiri maka bisa dipilih alternatif karier yang tepat bagi dirinya. Informasi tentang konsep diri peserta didik ini penting bagi pendidik untuk memotivasi belajar peserta didik dengan tepat. ${ }^{27}$ Hal ini masih jarang dilakukan oleh guru-guru di MTs Negeri 2 Kotamobagu, lebih banyak para guru memandang anak didik itu sama dalam proses pembelajaran, pada hal kita tahu bersama bahwa ada beberapa anak yang mungkin jika kita evaluasi dirinya secara individu akan berbeda dengan siswa yang lain.

Ranah afektif merupakan urgensi dalam meningkatkan hasil belajar siswa di MTs Negeri 2 Kotamobagu, sebab berkaitan dengan pembentukan sikap anak selama pembelajaran dan siswa dapat mengetahui kelemahan-kelemahannya dalam pembelajaran, contoh: tidak memperhatikan guru ketika proses pembelajaran, hal ini

24 Sukanti, "Penilaian Afektif Dalam Pembelajaran Akuntansi, Jurnal Pendidikan Akuntansi Indonesia”, Vol. IX (1) Tahun 2011, h. 76

${ }^{25}$ Sukanti, Penilaian Afektif...h. 76

${ }^{26}$ Sukanti, Penilaian Afektif... h.77

${ }^{27}$ Sukanti, "Penilaian Afektif...h. 77 
menunjukkan siswa tersebut masih kurang dari aspek sikap.

Awal berlakunya kurikulum 2013 Kepala madrasah masih belum memahaminya, karena pada saat munculnya kurikulum 2013 ini, terjadi perubahan yang signifikan jika dibandingkan dengan kurikulum tingkat satuan pendidikan (KTSP), sehingga harus memahami konteks evaluasi ranah afektif berbasis kurikulum 2013. Dengan adanya berbagai pelatihan dan belajar autodidak. Kegiatan-kegiatan pada implementasi ranah afektif di madrasah, berdasarkan pada penyusunan program tahunan dan program semester. Kepala madrasah memahami konsep dari kurikulum 2013, dimana pengembangan kompetensi siswa dapat mencakup 3 (tiga) aspek yaitu ranah afektif, kognitif dan psikomotor. Ranah afektif memegang peranan penting dalam meningkatkan kompetensi sehingga Kepala madrasah selalu melakukan pengawasan tentang perkembangan siswa di MTs Negeri 2 Kotamobagu. Berbagai pelatihan dan bimbingan teknis dilaksanakan, seperti: MGMP (Musyawarah Guru Mata Pelajaran) menjadi salah satu wadah untuk melakukan sosialisasi kurikulum 2013, untuk itu guru yang mengikuti kegiatan tersebut harus benar-benar serius, mengikutinya hal ini penting agar supaya dapat mengimplementasikan di madrasah.

\section{Problematika Penerapan Evaluasi Ranah Afektif Siswa pada Pembelajaran Berbasis Kurikulum 2013 di MTs Negeri 2 Kotamobagu}

Selanjutnya problematika guru dalam melakukan evaluasi terhadap ranah afektif di MTs Negeri 2 Kotamobagu, di madrasah penerapan kurikulum 2013 sudah dilaksanakan, akan tetapi ada berbagai perubahan dalam kurikulum termasuk berkaitan dengan penilaian.

Sesuai wawancara dengan guru berkaitan dengan pengalaman dalam melakukan evaluasi, peneliti menemukan sejumlah faktor utama yang menjadi problematika dalam evaluasi pada ranah afektif, yaitu:

a. Seringkali adanya perbedaan persepsi tentang batasan materi-materi yang tidak dapat dievaluasi dengan baik khususnya pada ranah afektif, hal ini terjadi karena guru lebih fokus pada substansi materi yang ada pada ranah kognitif. Di samping itu instrumen-instrumen yang dibuat oleh guru belum sampai pada penilaian ranah afektif. Seperti wawancara dengan guru di MTs Negeri 2 Kotamobagu "saya lebih fokus pada materi yang diajarkan, membuat strategi yang dapat meningkatkan pemahaman siswa tentang materi yang saya ajarkan, untuk sikap biasanya sudah di ketahui siswa yang baik dan tidak baik di dalam kelas, namun tidak menyusun penilaian secara berkala". Dari uraian tersebut maka sebenarnya sudah melakukan penilaian pada ranah afektif akan tetapi belum maksimal, karena hanya mengamati apa yang terjadi di dalam kelas. Instrumen-instrumen belum di susun oleh guru tersebut dalam melakukan penilaian terhadap siswa khususnya pada ranah afektif.

b. Persoalan pada tujuan pembelajaran; tujuan pembelajaran lebih diarahkan pada ranah kognitif di mana meningkatkan pemahaman tentang substansi materi, terlihat guru di MTs Negeri 2 Kotamobagu tujuan pembelajaran lebih difokuskan pada pengetahuan dan praktik, Pada hal kita tahu bersama bahwa ranah afektif merupakan bagian dari kompetensi yang harus ditanamkan terhadap siswa. sebagaimana peneliti melakukan pengamatan di dalam kelas pada siswa kelas 7 di MTs Negeri 2 Kotamobagu terlihat dalam memberikan materi masih terfokus pada 
kemampuan kognitif siswa, untuk ranah afektif masih pada batas berdoa sebelum dan sesudah pembelajaran, serta melihat siswa-siswa yang dianggap bermasalah.

c. Secara umum masih ditemukan persoalan klasik berupa kurangnya kemampuan sebagian besar guru dalam mengembangkan instrumen penilaian pada ranah afektif dan psikomotorik, dan lebih sering terbatas pada ranah kognitif. Kendati demikian, memang diakui banyak ahli bahwa evaluasi untuk ranah afektif cenderung 'lebih sulit' bila dibanding ranah lain, namun bukan berarti tidak dapat dilakukan secara ideal. Sebagaimana hasil wawancara dengan kepala madrasah yaitu “...banyak guru yang mengajar namun belum menyiapkan pembelajaran yang lengkap, salah satunya adalah instrumen penilaian pada ranah afektif, terlihat masih kurang, instrumen yang lengkap hanya pada ranah kognitif, berupa tes tertulis...." Hal ini menunjukkan bahwa perlu adanya perbaikan atau pelatihan berkaitan dengan pengembangan ranah afektif.

d. Isu yang berkembang di kalangan guru bahwa merasa sulit untuk penilaian berbasis kurikulum 2013, sebagaimana wawancara dengan wakil kepala kurikulum "...saya melihat guru mengalami kesulitan pada penilaian untuk kurikulum 2013, mereka menganggap bahwa penilaian hanya menjadi baban tugas dalam mengajar...". Jadi dari hasil wawancara tersebut menunjukkan masih perlu ditingkatkan pemahaman tentang kurikulum 2013 khususnya pada penilaian berbasis kurikulum 2013. ${ }^{28}$

Terhadap sejumlah persoalan di atas, terdapat sejumlah strategi yang dapat dilakukan dalam usaha meningkatkan Proses menilai hasil pendidikan dan pembelajaran secara efektif. Hal ini agar penilaian dapat dilakukan terhadap semua aspek hasil belajar secara serasi dan seimbang sehingga aspek afektif tidak menjadi terabaikan. Sejumlah strategi yang dimaksud antara lain: Perumusan tujuan yang jelas dan tegas sehingga mudah dievaluasi; Pencatatan tingkah laku peserta didik; Kesinambungan dalam penilaian; Kualitas instrumen dalam penilaian; dan Kesesuaian antara aspek yang diukur dengan metode yang disampaikan. ${ }^{29}$

Secara teknis usaha-usaha yang harus dilaksanakan untuk meningkatkan kemampuan evaluasi pada rana afektif, sebagai berikut:

a. Perancangan penilaian oleh guru dilakukan saat Pengembangan program pembelajaran, baik dalam bentuk silabus maupun rencana pelaksanaan pembelajaran (RPP).

b. UTS dan UAS adalah teknik penilaian untuk mengukur ketuntasan penguasaan kompetensi dari siswa pada tengah semester dan akhir semester. Di samping itu harus mengukur ranah afektif siswa, karena pada model rapor kurikulum 2013 sudah ada lembar penilaian untuk ranah afektif (KI-1: kompetensi spiritual dan KI2: kompetensi sosial)

c. Penilaian tugas terstruktur dan mandiri adalah teknik penilaian untuk mengukur ke dalaman pengamalan ajaran agama dan aktivitas keagamaan siswa dalam keseharian

\footnotetext{
${ }^{28}$ Rekapitulasi hasil wawancara dengan Kepala sekolah, Wakil, dan Guru di MTs Negeri 2 Kotamobagu

${ }_{29}$ Peggy Joy Jenkins, Memupuk dan Mengembangkan Nilai-Nilai Spritual pada Anak (Jakarta: Gramedia Pustaka Utama, 2010), h. 38
} 
d. penilaian tugas kelompok melalui diskusi adalah teknik untuk mengukur keluasan pemahaman dan pengetahuan siswa. pengembangan ranah afektif diarahkan pada saling membantu dan bekerjasama selama proses pembelajaran di dalam kelas.

e. Penilaian kehadiran adalah teknik untuk menilai komitmen siswa dalam melaksanakan kewajibannya sebagai seorang peserta didik; dan

f. Penilaian spiritual dan sosial, yakin teknik untuk mengetahui sikap dan amaliah siswa dalam kehidupan di lingkungannya. ${ }^{30}$

Dari uraian di atas maka ada beberapa hal yang sudah dilaksanakan yaitu penilaian kehadiran siswa di dalam kelas, dan juga melakukan pembimbingan penyusunan instrumen penilaian ranah afektif dalam bentuk bimbingan teknis oleh guru-guru yang ada di MTs Negeri 2 Kotamobagu.

\section{Solusi Terhadap Problematika Penerapan Evaluasi Ranah Afektif Siswa pada Pembelajaran Berbasis Kurikulum 2013 di MTs Negeri 2 Kotamobagu}

Tindak lanjut terhadap pemecahan masalah siswa di madrasah sangatlah penting, karena permasalahan siswa dalam pembelajaran akan berpengaruh terhadap hasil belajar dari anak tersebut. terutama berkaitan dengan ranah afektif khususnya siswa mempunyai keinginan untuk belajar.

Seorang pendidik sebaiknya mengetahui afektif peserta didik sehingga dapat diketahui status afektif peserta didiknya. Jika afektif tinggi maka perlu mempertahankannya, jika rendah perlu upaya untuk meningkatkannya. Suharsimi Arikunto (2003) menjelaskan pengukuran ranah afektif tidak dapat dilakukan setiap saat (dalam arti pengukuran formal) karena perubahan tingkah laku siswa tidak dapat berubah sewaktu-waktu. Pengubahan sikap seseorang memerlukan waktu yang relatif lama. Demikian juga pengembangan minat dan penghargaan serta nilai-nilainya. Sasaran penilaian afektif adalah perilaku peserta didik bukan pengetahuannya. ${ }^{31}$ Sesuai dengan karakteristik afektif dalam proses pembelajaran adalah minat, sikap, konsep diri dan nilai maka tujuan penilaian afektif adalah:

a. Untuk memperoleh informasi minat peserta didik terhadap mata pelajaran yang selanjutnya digunakan untuk meningkatkan minat peserta didik terhadap mata pelajaran jika ternyata minatnya rendah.

b. Untuk mengetahui sikap peserta didik terhadap mata pelajaran di madrasah. Sikap peserta didik terhadap mata pelajaran dapat positif atau negatif. Hasil pengukuran sikap berguna untuk menentukan strategi pembelajaran yang tepat untuk peserta didik.

c. Untuk mengetahui kekuatan dan kelemahan diri sendiri. Peserta didik melakukan evaluasi terhadap potensi yang ada dalam dirinya. Informasi ini dapat digunakan untuk menentukan program yang sebaiknya ditempuh peserta didik untuk menentukan jenjang karier.

${ }^{30}$ Kementerian Pendidikan dan Kebudayaan, Panduan Penilaian Oleh Pendidik dan Satuan Pendidikan Untuk Sekolah Menengah Pertama (Jakarta: Direktorat Pendidikan Dasar dan Menengah, 2016), h.21

${ }^{31}$ Suharsimi Arikunto, Pengantar Evaluasi Pembelajaran (Bandung, Alfabeta, 2003), h.92 
d. Untuk mengungkap nilai individu. Informasi yang diperoleh ini berupa nilai yang positif dan yang negatif. Hal-hal yang positif diperkuat dan yang negatif diperlemah dan akhirnya dihilangkan. ${ }^{32}$

Ranah afektif memegang peranan penting terhadap pengembangan kompetensi siswa di madrasah. Berbagai kompetensi yang harus ditanamkan terhadap siswa di MTs Negeri 2 Kotamobagu, untuk itu perlu evaluasi ranah afektif sebagai kunci untuk meningkatkan keinginan anak untuk belajar.

Di MTs Negeri 2 Kotamobagu guru kelas yang dominan untuk melakukan penilaian terhadap ranah afektif (sikap) siswa, sementara tuntutan Kurikulum 2013 mengharuskan untuk semua guru bertanggung jawab terhadap ranah afektif siswa. Hal yang dilakukan oleh Kepala MTs Negeri 2 Kotamobagu yaitu melakukan bimbingan terhadap guru dan memberikan penugasan agar guru-guru membuat laporan perkembangan ranah afektif siswa.

Dengan adanya evaluasi ranah afektif, maka guru berperan sebagai:

a. Keeping track, yaitu untuk menelusuri dan melacak proses belajar peserta didik sesuai dengan rencana pelaksanaan pembelajaran yang telah ditetapkan. Untuk itu, guru harus mengumpulkan data dan informasi dalam kurun waktu tertentu melalui berbagai jenis dan teknik penilaian untuk memperoleh gambaran tentang pencapaian kemajuan.

b. Checking-up, yaitu untuk mengecek ketercapaian kemampuan peserta didik dalam proses pembelajaran dan kekurangan-kekurangan peserta didik selama mengikuti proses pembelajaran. Dengan kata lain, guru perlu melakukan penilaian untuk mengetahui bagian mana dari materi yang sudah dikuasai peserta didik dan bagian mana dari materi yang belum dikuasai.

c. Finding-out, yaitu untuk mencari, menemukan dan mendeteksi kekurangan kesalahan atau kelemahan peserta didik dalam proses pembelajaran, sehingga guru dapat dengan cepat mencari alternatif solusinya.

d. Summing-up, yaitu untuk menyimpulkan tingkat penguasaan peserta didik terhadap kompetensi yang telah ditetapkan. Hasil penyimpulan ini dapat digunakan guru untuk menyusun laporan kemajuan belajar ke berbagai pihak yang berkepentingan.

Dengan menerapkan peran guru tersebut, maka mempermudah guru dalam membuat evaluasi ranah afektif siswa di MTs Negeri 2 Kotamobagu. Peran guru sebagai checking-up guru dapat membuat analisis-analisis terhadap pencapaian kompetensi siswa, sehingga guru dapat menyusun laporan perkembangan sikap (afektif) siswa di madrasah. Menurut guru di MTs Negeri 2 Kotamobagu, ada keterkaitan antara kompetensi afektif dengan hasil belajar siswa, karena secara umum jika ranah afektifnya baik maka hasil belajarnya juga menjadi baik. Di kelas VII ada beberapa siswa nakal mempunyai nilai ulangan harian yang rendah, dan beberapa siswa yang rajin mendapatkan tuntas pada kriteria ketuntasan minimal (KKM) yang ditetapkan oleh madrasah.

\footnotetext{
${ }^{32}$ Suharsimi Arikunto, Pengantar...,h. 93
} 
Dalam Kurikulum 2013 penanaman sikap diintegrasikan ke dalam pembelajaran, inovasi terbaru dalam pendidikan karakter di madrasah adalah mengintegrasikan pendidikan karakter dalam semua mata pelajaran yang ada, baik melihat pemuatan nilainilai ke dalam substansi maupun melihat pelaksanaan kegiatan pembelajaran yang memfasilitasi dipraktikkannya nilai-nilai karakter dalam setiap aktivitas pembelajaran di dalam dan diluar kelas. di samping itu, pendidikan karakter juga bisa diintegrasikan ke dalam pelaksanaan kegiatan ekstrakurikuler di madrasah. untuk mendukung pendidikan karakter di kelas dan dalam kegiatan kesiswaan ini, manajemen madrasah harus di rancang dan dilaksanakan dengan tujuan mendukung terrealisasinya nilai-nilai karakter di kalangan semua warga madrasah. Dengan kata lain, pembentukan kultur madrasah menjadi sangat penting dalam mendukung suksesnya pendidikan karakter di madrasah. ${ }^{33}$ Hal ini menunjukkan ada keterkaitan antara sikap siswa dengan hasil belajar, jika sikap siswa yaitu mempunyai keinginan untuk belajar baik maka hasil belajar siswa juga menjadi lebih baik. Hal ini dapat dibuktikan dengan hasil penilaian guru di MTs Negeri 2 Kotamobagu di mana rata-rata siswa yang tuntas dalam pembelajaran, mempunyai sikap yang baik terhadap proses pembelajaran di dalam kelas. interaksi yang baik antara siswa dan siswa, serta siswa dan guru memegang peranan penting untuk membangun ranah afektif siswa, untuk itu guru di MTs Negeri 2 Kotamobagu harus mempunyai interaksi yang baik selama proses pembelajaran.

Selanjutnya pelanggaran-pelanggaran yang seringkali dilakukan oleh siswa di MTs Negeri 2 Kotamobagu, yaitu:

Pelanggaran-Pelanggaran Domain Ranah Afektif Siswa di MTs Negeri 2 Kotamobagu

\begin{tabular}{|c|c|c|}
\hline No & Pelanggaran & Solusi \\
\hline 1 & $\begin{array}{l}\text { Datang terlambat ke } \\
\text { madrasah }\end{array}$ & Guru piket melakukan pembinaan terhadap siswa \\
\hline 2 & Pulang tidak tepat waktu & $\begin{array}{l}\text { Guru piket melakukan pembinaan, jika masih } \\
\text { tetap melakukan pelanggaran, maka panggil } \\
\text { orang tua siswa, untuk membicarakan } \\
\text { permasalahan siswa tersebut }\end{array}$ \\
\hline 3 & $\begin{array}{l}\text { Tidak mengerjakan } \\
\text { tugas }\end{array}$ & $\begin{array}{l}\text { Melakukan pembinaan, dan memberikan tugas } \\
\text { tambahan terhadap siswa }\end{array}$ \\
\hline 4 & $\begin{array}{l}\text { Tidak sholat dzuhur } \\
\text { berjamaah }\end{array}$ & Melakukan pembinaan terhadap siswa tersebut \\
\hline 5 & Menyontek ketika ujian & $\begin{array}{l}\text { Memindahkan siswa tersebut di tempat yang } \\
\text { mudah untuk di awasi guru dan tetap melakukan } \\
\text { pembinaan terhadap siswa tersebut- }\end{array}$ \\
\hline
\end{tabular}

Sumber: Hasil Wawancara dan Observasi di MTs Negeri 2 Kotamobagu

${ }^{33}$ Marzuki, Pendidikan..., h.7 
Dari uraian di atas maka pelanggaran-pelanggaran berkaitan dengan pengembangan ranah afektif di MTs Negeri 2 Kotamobagu terdiri dari disiplin waktu, tidak mengerjakan tugas, tidak sholat berjamaah, dan menyontek ketika ujian. Dari pelanggaran tersebut secara umum solusi yang dilakukan oleh guru di MTs Negeri 2 Kotamobagu yaitu melakukan pembinaan, juga melibatkan orang tua siswa untuk menangani masalah-masalah yang dihadapi oleh siswa.

Untuk mengatasi masalah tersebut maka perlu untuk meningkatkan motivasi belajar siswa. Pentingnya motivasi dalam pembelajaran, sebagaimana menurut Nana Sudjana salah satu indikator afektif adalah motivasi berkaitan dengan kesiapan siswa untuk menerima atau merespon pembelajaran. Adanya respon yang baik, maka selama proses pembelajaran siswa akan menjadi lebih aktif sehingga mudah untuk mentransfer materi-materi yang diajarkan oleh guru. ${ }^{34}$

Dalam proses belajar, motivasi sangat diperlukan sebab yang tidak mempunyai motivasi dalam belajar, tidak akan mungkin melakukan aktivitas belajar. Ciri-ciri motivasi belajar menurut Sardiman (2007:83) motivasi yang ada pada diri setiap orang itu memiliki ciri-ciri. Adapun ciri-ciri yang diungkapkan sebagai berikut :

a. Tekun menghadapi tugas (dapat bekerja terus-menerus dalam waktu yang lama, tidak pernah berhenti sebelum selesai). Hal ini sangat penting untuk diperhatikan oleh guru di MTs Negeri 2 Kotamobagu, dengan bantuan guru maka anak-anak harus diberikan motivasi agar supaya tekun dalam mengerjakan tugas-tugas.

b. Ulet menghadapi kesulitan (tidak lekas putus asa).tidak memerlukan dorongan dari luar untuk berprestasi sebaik mungkin (tidak cepat puas dengan prestasi yang telah dicapainya). Guru di MTs Negeri 2 Kotamobagu terus melakukan bimbingan dan arahan terhadap siswa, dalam menghadapi kesulitan siswa tersebut untuk mengembangkan kompetensinya.

c. Menunjukkan minat terhadap bermacam-macam masalah, siswa di MTs Negeri 2 Kotamobagu harus mempunyai minat terhadap mata pelajaran di madrasah.

d. Lebih senang bekerja mandiri, dalam proses pembelajaran jika seorang siswa termotivasi maka di cenderung untuk mengerjakan tugas-tugas yang diberikan oleh guru.

e. Cepat bosan pada tugas-tugas yang rutin (hal-hal yang bersifat mekanis, berulang- ulang begitu sehingga kurang kreatif). Intensitas untuk mengerjakan hal-hal yang baru merupakan tantang tersendiri dari siswa-siswa selama proses pembelajaran.

f. Dapat mempertahankan pendapatnya, dalam diskusi kelompok akan terlihat keinginannya untuk mengemukakan pendapat, dan jika pendapat tersebut sesuai dengan teori maka kecenderungan untuk mempertahankan pendapat tersebut.

\footnotetext{
${ }^{34}$ Nana Sudjana, Penilaian ..., h.24
} 
g. Tidak mudah melepaskan hal yang diyakini itu. Siswa akan cenderung belajar, sehingga dengan belajar maka meningkatkan keyakinan siswa terhadap materimateri yang disampaikan oleh guru.

h. Senang mencari dan memecahkan masalah soal-soal. Jadi guru di MTs Negeri 2 Kotamobagu harus mampu untuk memberikan contoh-contoh soal atau kasus, untuk diselesaikan oleh siswa, sehingga mereka akan terus memecakan soal atau kasus yang diberikan oleh guru. ${ }^{35}$

Jadi ranah afektif berpengaruh terhadap hasil belajar siswa. Salah satu ranah afektif siswa adalah motivasi belajar, jika motivasi belajar tinggi maka hasil belajar juga akan tinggi. sebagaimana uraian diatas bada ada 3 orang siswa di MTs Negeri 2 Kotamobagu merupakan siswa yang berprestasi, begitu juga dengan sikapnya yang baik di mana mengerjakan tugas yang diberikan guru serta tidak terlambat datang ke kelas. Perlu adanya penekanan terhadap ranah afektif siswa, karena baik tidaknya anak tersebut tergantung pada sikap yang dimiliki oleh anak tersebut. Untuk itu perlu adanya instrumen-instrumen penilaian ranah afektif yang dipahami oleh guru-guru yang ada di MTs Negeri 2 Kotamobagu. Instrumen-instrumen tersebut disusun oleh guru berdasarkan aturan-aturan yang ada dalam kurikulum $2013 .^{36}$

\section{Penutup}

\section{A. Kesimpulan}

1. Implementasi evaluasi ranah afektif di MTs Negeri 2 Kotamobagu secara umum sudah dilaksanakan namun belum maksimal, indikasinya metode evaluasi hanya menggunakan observasi dengan instrumen lembar observasi. Pada ranah afektif kompetensi inti spiritual (KI-1) yaitu: berdoa sebelum dan sesudah belajar, sholat dzuhur berjamaah, dan membaca surah-surah pendek. Ranah afektif kompetensi inti sosial (KI-2) yaitu disiplin, jujur, dan saling membantu. Secara umum kompetensi inti spiritual dan sosial sudah dilaksanakan oleh siswa di MTs Negeri 2 Kotamobagu, dan hanya beberapa siswa yang melakukan pelanggaran terhadap kompetensi tersebut.

2. Problematika evaluasi ranah afektif di MTs Negeri 2 Kotamobagu, guru belum memahami dengan baik tentang pengukuran ranah afektif siswa, sehingga penilaian hanya berdasarkan pengamatan di dalam kelas, tanpa ada catatan tentang sikap siswa selama pembelajaran. Di samping itu dibenak para guru bahwa penilaian ranah afektif terhadap siswa dianggap masih sulit, karena harus melakukan pengamatan pada masing-masing siswa selama proses pembelajaran.

3. Solusi terhadap problematika evaluasi ranah afektif siswa di MTs Negeri 2 Kotamobagu berkaitan dengan teknik evaluasi, maka kepala madrasah menginstruksikan kepada guru untuk membuat laporan evaluasi sikap. Untuk mengatasi permasalahan berkaitan dengan pelanggaran terhadap ranah afektif

\footnotetext{
${ }^{35}$ A.M. Sardiman, Interaksi dan Motivasi Belajar Mengajar (Jakarta: Raja Grafindo Persada, 2007), h.83

${ }^{36}$ Hamid Muhammad, Panduan..., h.58
} 
siswa, maka guru melakukan bimbingan terhadap siswa di MTs Negeri 2 Kotamobagu.

\section{B. Implikasi}

1. Adanya evaluasi pengembangan ranah afektif siswa dalam proses pembelajaran berbasis kurikulum 2013, maka mempunyai implikasi yang positif dalam mengembangkan ilmu manajemen pendidikan yang difokuskan pada evaluasi pembelajaran berbasis kurikulum 2013.

2. Dengan meningkatnya kemampuan guru dalam melakukan evaluasi terhadap ranah afektif siswa, maka berimplikasi pada peningkatan kemampuan guru untuk menyusun instrumen dan mengukur ranah afektif berbasis kurikulum 2013 pada siswa MTs Negeri 2 Kotamobagu Standar instrumen evaluasi ranah afektif yaitu teknik observasi, penilaian diri sendiri, penilaian antar teman, dan penilaian jurnal.

\section{Rekomendasi}

1. Madrasah harus membuat program bimbingan teknis dan selalu melakukan pengawasan kepada guru-guru MTs Negeri 2 Kotamobagu untuk menyusun instrumen penilaian termasuk penilaian sikap, pengetahuan, dan praktik, implikasinya guru dapat memahami instrumen penilaian sehingga dapat menyusun instrumen penilaian dengan baik. Hal ini penting karena masih banyak guru yang tidak memahami tentang penyusunan dan penggunaan instrumen evaluasi ranah sikap.

2. Kepala madrasah dan pengawas memeriksa kelengkapan perangkat pembelajaran dari guru MTs Negeri 2 Kotamobagu termasuk memeriksa RPP yang didalamnya ada instrumen penilaian 3 (tiga) ranah yaitu sikap, pengetahuan, dan praktik, serta melakukan perbaikan terhadap instrumen yang disusun oleh guru di MTs Negeri 2 Kotamobagu.

\section{Daftar Pustaka}

Al-Qur'an Transliterasi Latin Terjemah Indonesia, Jakarta: Suara Agung, 2015

A.M. Sardiman, Interaksi dan Motivasi Belajar Mengajar Jakarta: Raja Grafindo Persada, 2007

Arikunto, Suharsimi, Pengantar Evaluasi Pembelajaran Bandung, Alfabeta, 2003

Asrul, dkk, Evaluasi Pembelajaran Bandung: Citapustaka Media, 2014

Darmadji, Ahmad, "Urgensi Ranah Afektif Dalam Evaluasi Pendidikan Agama Islam di Perguruan Tinggi Umum”,

Departemen Agama RI, Al-Qur'an Transliterasi Latin Terjemah Indonesia, Jakarta: Suara Agung, 2015

Jenkins, Peggy Joy, Memupuk dan Mengembangkan Nilai-Nilai Spritual pada Anak Jakarta: Gramedia Pustaka Utama, 2010

Jurnal Unisia, Vol. XXXIII (74) Tahun 2014 
Kementerian Pendidikan dan Kebudayaan, Panduan Penilaian Oleh Pendidik dan Satuan Pendidikan Untuk Sekolah Menengah Pertama Jakarta: Direktorat Pendidikan Dasar dan Menengah, 2016

Kementerian Pendidikan dan Kebudayaan, Panduan Penilaian Oleh Pendidik dan Satuan Pendidikan Untuk Sekolah Menengah Pertama Jakarta: Direktorat Pendidikan Dasar dan Menengah, 2016

Marwan bin Musa, Abu Yahya, Tafsir Al Qur'an Hidayatul Insan, Jilid 1.

Nurdin, Syafruddin dan Adriantoni, Kurikulum dan Pembelajaran, Jakarta: Rajawali Pers, 2016

Purwanto,Ngalim, Prinsip-Prinsip dan Teknik Evaluasi Pengajaran Bandung: Remaja Rosdakarya, 2000

Sanjaya, Wina, Strategi Pembelajaran Berorientasi Standar Proses Pendidikan Jakarta: Prenada Media Group, 2006

Slameto, Belajar dan Faktor-faktor yang Mempengaruhinya Jakarta: Rineka Cipta, 2013

Sugiyono, Memahami Penelitian Kualitatif Bandung: Alfabeta, 2003

Sukanti, "Penilaian Afektif Dalam Pembelajaran Akuntansi, Jurnal Pendidikan Akuntansi Indonesia", Vol. IX (1) Tahun 2011

Undang-Undang Nomor 20 tahun 2003 tentang Sistem Pendidikan Nasional, pasal 1

Wawancara dengan AM Kepala MTs Negeri 2 Kotamobagu pada tanggal 3 Juli 2018

Wawancara dengan wakil kepala Madrasah Inisial DSP di MTs Negeri 2 Kotamobagu pada tanggal 5 Juli 2018

Wawancara dengan guru Inisial LU di MTs Negeri Kotamobagu, pada tanggal 9 Juli 2018 